\title{
ACQUISITION OF TURKISH GRAMMATICAL CATEGORIES IN BILINGUAL CONTEXT
}

\author{
Hristo Kyuchukov \\ hkyuchukov@gmail.com \\ University of Silesia, Poland
}

Received April 17, 2019; Revised June 19, 2019; Accepted June 22, 2019

\begin{abstract}
The paper presents results form a study on acquisition of Turkish grammatical categories by first grade Turkish speaking minority children in Bulgarian primary school. Two groups of children speakers of Turkish are tested: ethnic Turks and ethnic Roma. The Roma are Muslims and are also speakers of Turkish. Both groups speak the Northeast variety of Turkish, spoken in the surroundings of Varna, Bulgaria. The author examines the lexical reaches, syntax complexity and narrative knowledge of the children and predicts that the low results on mother tongue tests will be a reason for difficulties in the second language acquisition - Bulgarian. The author connects the results of mother tongue knowledge of the children with the language interdependence theory of Cummins (1991), where the level of the mother tongue is a predictor of second language acquisition.
\end{abstract}

Keywords: Turkish, mother tongue, bilingualism, Bulgaria.

\section{Кючуков Хрісто. Опанування граматичних категорій турецької мови у контексті двомовності.}

Анотація. У поданій статті представлено результати проведеного дослідження, що присвячене опануванню граматичних категорій турецької мови учнями першого класу турецької мовної меншини в болгарській початковій школі. В цьому тестуванні взяли участь дві групи дітей, які спілкуються турецькою: етнічні турки та етнічні роми. Роми, котрі стали учасниками дослідження, є мусульманами та розмовляють турецькою. Обидві протестовані групи говорять на північно-східній різноманітності турецької мови, якою розмовляють на околицях м. Варна, Болгарія. Автор досліджує лексичний запас, синтаксичну складність та наративні знання дітей і робить припущення, що низькі результати під час тестування рідної мови можуть стати причиною труднощів при освоєнні другої мови болгарської. Автор пов'язує результати знань рідної мови у дітей з теорією взаємозалежності мови Кумінса (1991), згідно якої рівень володіння рідною мовою $є$ предиктором вивчення другої мови.

Ключові слова: турецька, рідна мова, двомовність, Болгарія.

\section{Introduction}

Turkish minority is one of the biggest minorities in Bulgaria. According to the census from 2011 their number is approximately 588. 000 or $8,8 \%$ from the total population. However, one part of the Muslim Roma in Bulgaria is also Turkish speaking and they identify in most of the cases as Turks as well. The total number of the Turkish speaking community in the country is approximately 606000 or $9.1 \%$.

\footnotetext{
(C) Kyuchukov, Hristo, 2019. This is an Open Access article distributed under the terms and conditions of the Creative Commons Attribution 4.0 International Licence (http://creativecommons.org/ licenses/by/4.0).

East European Journal of Psycholinguistics, 6(1), 32-46. https://doi.org/10.5281/zenodo.3375406
} 
The last 30 years the position of the Turkish minority in the society became very high - there is a Turkish party, which is the third political power after the Democratic and Communist party in the country and thanks to this the Turkish minority have obtain many rights in Bulgaria. One of the very first rights which they got after the democratic changes in 1990 is the right to have their names back, because during the communist regime the names of the Muslims (Turks, Roma, Pomaks) were changed by force. The second right which they got was to study their mother tongue organized in schools $4 \mathrm{~h}$ per week, together with other minorities such as Armenians, Jewish and Roma. However, the mother tongue classes have been introduced only in primary schools (grades 1 to 8 ), but not in kindergartens (Kyuchukov, 2007).

The Turkish parents usually speak a dialect. The Turkish dialects in Bulgaria are divided into two main groups: ka-dialect in Deliorman in Northeast Bulgaria and ga-dialect in South Bulgaria (Kyuchukov, 2019). Often the dialects have Bulgarian words, words from Arabica and archaic words from Ottoman Turkish. Last 20 years thanks to the satellite-TV and contacts with Turkey the Bulgarian Turks learned also the official Turkish from Turkey. However, the children still have problems with mastering their mother tongue. How much the children learn their mother tongue from the communication with their parents and what is the role of the parents in this process of language learning? These are the questions which I will try to answer and for this reason I check the knowledge of the children in Turkish as their mother tongue.

Some 60 years ago Luria and Yudovich (1959) claimed that the adults play an important role in the life of the children - naming objects and defining their connections with the world, helping the children to get their own individual experiences playing with words. The authors also explain the importance of the mothers, when she shows the child different objects and names them - in this way she influences the formation of his/her mental processes. All children from all cultures have the same way of developing the mental processes and this is mainly through the communication with the adults.

Aksu-Koç and Slobin (1985) conducted a research on acquisition of Turkish by monolinguals. They discovered that when children learnt Turkish at home, they do not make mistakes, i.e. their speech resembled that of their parents. Therefore, the parents and their way of speaking is so important.

Almost in all West European countries Turkish has a low prestige. Akınc1 (2017) reports that the Turkish children in France, although have organized lessons in kindergarten level in Turkish as a mother tongue, do not have good knowledge of their vocabulary and syntax. The author's explanation for the low knowledge of their mother tongue is due to the low prestige of Turkish in France. The same can be said for Germany, Sweden, Denmark and England.

In some Western countries where Turkish immigrants live, as for example in the Netherlands and Germany, several researches with Turkish children have been carried out. For instance, and Boeschoten and Verhoeven (1987) studied Turkish children between 4 and 8 years of age living in the Netherlands and Turkey. They 
established by measuring some linguistic categories that there were not significant differences between five-year old children from Dutch cities and from Central Anatolia in Turkey. However, some differences appear at the age of 7. A similar research on Turkish children living in Berlin, Germany was conducted by Pfaff (1993). The results of the Turkish children living in Berlin differed from those achieved by the Turkish children from the Netherlands.

Boeschoten (1990) focuses on the vocabulary and word formation of the Turkish language and how lexical units are acquired by children at home or in school for communication purposes, how children produce complex sentences and learn suffixes forming verbal tenses as well as aspects and modality. Other studies by Verhallen and Schoenen (1993) and Verhoeven (1993) research bilingual Turkish children and their lexical knowledge of mother tongue. All of them show that the Turkish bilingual children have deficit in their mother tongue knowledge.

\section{Research methodology}

The main goal of the study is to find out what is the level of knowledge of Turkish by Turkish children and Turkish speaking Roma children (6-7 years old), when they enter the primary school in Bulgaria.

The research tasks are:

1. To assess children's vocabulary in Turkish as their mother tongue;

2. To assess their narrative competence.

Oral interviews were used as a research method. Children's answers were recorded with a cassette recorder and the tapes were transcribed and analyzed. The interviews were conducted at school, in a separate room, where the child and the interviewers are present only.

The children were given the following assignments:

a) Picture and verbal test (Test 1 and 2) to measure their vocabulary;

b) To retell a story after it was read (told) by the researcher.

\section{The Tests:}

\section{Picture and verbal test}

Test 1 contains five pictures with objects which had to be named by the children in their mother tongue - Turkish. The objects drawn on these pictures were taken from the surrounding environment and were a part of child's world (children, trees, flowers, sun, stones).

Test 2 was conducted two months later. Its aim was to study the functional meaning of some words. The children were shown objects from the classroom and were asked what their purpose was:

1. What is this? (A chair is pointed out.)

What do we use it for?

2. What is this? (A table is pointed out.)

What do we use it for?

3. What is this? (A blackboard is pointed out.)

What do we use it for? 


\section{What is this? (A filing cabinet is pointed out.)}

What do we put inside?

5. Who are they? (Students are pointed out.)

What are they doing?

To assess children's narrative competence at the beginning of the school year, the researcher read two stories and children had to retell them.

Tale A: Horozlan tilki (The Rooster and the Fox) in Turkish.

Tale B: Aç köpek (The Greedy Dog) in Turkish.

Between tale A and tale B there were two months of distance. The children in the study were divided into the following groups:

Group 1: 8 Turkish children in grade 1 speaking Northeastern Turkish dialect and living in the village of Slaveykovo, Varna region.

Group 2: 8 Turkish speaking Roma children in preparatory class (the same age as the Turkish children form Group 1) speaking the same Turkish dialect, but living in the town of Provadiya, Varna region.

These two groups of children were given Tests 1 and 2 and they had to retell stories as well.

Some children have attended a kindergarten and can speak Bulgarian but make mistakes. All children are bilingual, but their Bulgarian is not fluent. They communicate in Turkish at home and use Bulgarian at school. They are not sufficiently proficient in Bulgarian, neither in their mother tongue.

\section{Hypothesis:}

The design of the study gives us the bases to build up the following Hypothesis:

H1: The children living in the town will have better performance on the tests, than the children living in the village.

H2: The children living in a village will have better narrative skills than the children living in the town.

\section{Results}

\subsection{Vocabulary richness}

Results of Test 1 (picture naming Test)

The obtained results are given in Figure 1. Almost all subjects from group 1 (Turkish children from the village of Slaveykovo) named the objects except for 1 child who did not know the word sun in Turkish. The children from group 2 (Turkish speaking Roma from the town Provadiya) also did not know some words in their mother tongue - Turkish dialect - and substituted them the Bulgarian words. Sun turned out to be most difficult word for this group as well. Many children did not know the word at all or could not recognize the sun on a picture. There was one interesting fact - one of the subjects from this group used Bulgarian words to name all objects instead of Turkish. 


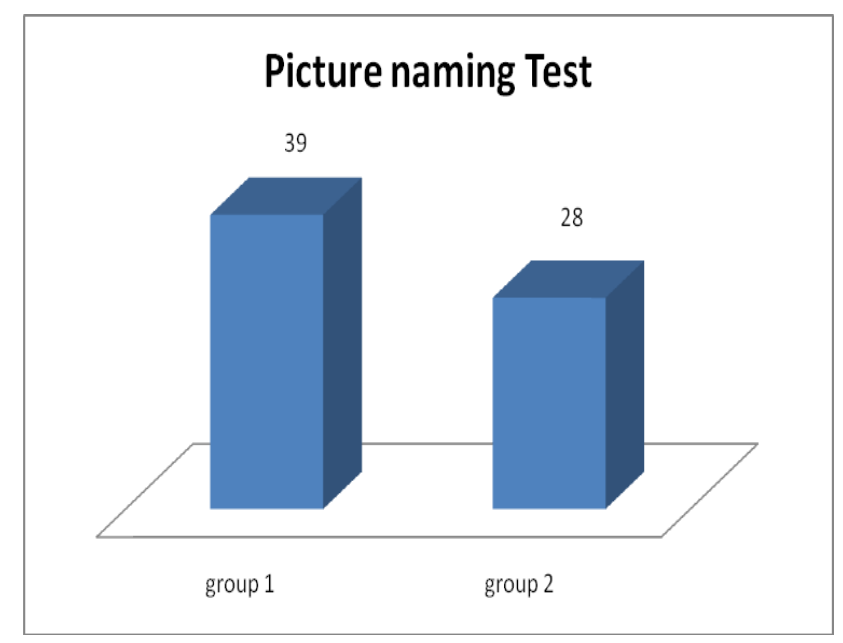

Figure1. Scores of Test 1

Comparing the groups, we can see that there are significant differences between them $(p>0.05)$. The knowledge of Turkish children from the village of Slaveykovo is greater than the knowledge of Turkish speaking Romani children from the town of Provadiya. What could be the reason for it? Before to answer this question let us see the results form the next test.

\section{Results of Test 2 (objects naming Test)}

In Test 2, children must name objects from the classroom and explain their function. The results are shown in Figure 2. The children were able to name the objects pointed out but could not explain their functions. All of them who had a score of 9 points did not know the functional meaning of some words. Children from different groups did not know the functional meaning of different words. For instance, the children from group 1 could not explain the words blackboard and filing cabinet, and the children from group 2 - of the Turkish word for students.

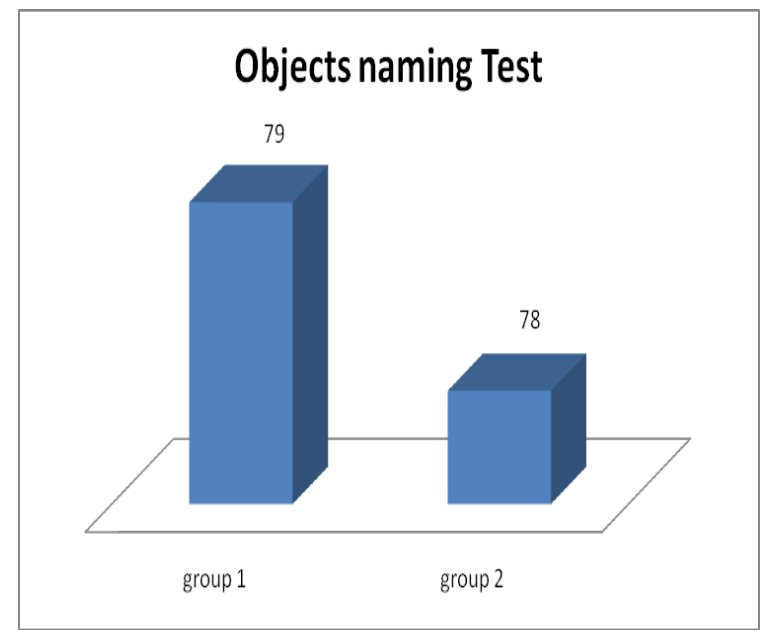

Figure 2. Scores of Test 2 
There are different reasons for such gaps in children's knowledge. They can be individual (the child does not know the meaning of a word), cultural (if there is not a word to designate an object in the respective culture) and social (their parents do not explain them the meaning of words). In our case, the reasons are mainly cultural and social. As one can see from the picture there are no statistical differences in the performance of the Test 2 .

\subsection{Lexical knowledge}

Children's vocabulary can be measured separately and in groups by the socalled Type-Token Ratio (TTR).

The children had the task to retell a tale in their mother tongue- Turkish, after they had heard it. The first tale (tale A) is called Horozlan tilki (The Cock and the Fox) and the second tale (tale B) is called Aç köpek (The Greedy Dog).

The total number of words used by the children is given in Table 1 . The comparison of the total number of words used for retelling the two tales shows that there are some differences. One of the reasons is the different length of the tales selected by the researchers. This is one of the weak points of our research - we did not take into consideration the total number of words of tales A and B. However, the obtained results provide interesting information about the three groups of subjects.

\section{Table 1}

Total number of words used for retelling tales $A$ and $B$

\begin{tabular}{lcc}
\hline & $\begin{array}{c}\text { Group 1 } \\
\text { Slaveykovo }\end{array}$ & $\begin{array}{c}\text { Group 2 } \\
\text { Provadia }\end{array}$ \\
\hline Tale A & 233 & 204 \\
Tale B & 201 & 209 \\
\hline
\end{tabular}

The total number of words of tale B is smaller than that of tale A. We should focus our attention on another important fact - some children are more communicative than others. For instance, one child from group 2 (from town of Provadiya) refused to retell the first story, and all words were actually produced by 7 children. Comparing the results of the groups one can see that the number of words used by the children from group 2 (Turkish speaking Roma children) in the second tale was higher than that in the first one. This may be because one of them refused to retell the first story.

The results obtained by comparing the Type-Token Ratio of the subjects and their groups are very interesting. Their lexical knowledge is illustrated in Figure 3.

The obtained results are very interesting. The lowest TTR measured in group 1 is 52.2 whereas the highest is 90 . The results of group 2 vary from 0 to 100 . What is significant is that there is not a TTR lower than 50 in this group. We should note that sometimes the higher TTR is a result of a shorter text. Group 1 achieved the best results with TTR of 81.1, i.e. they had the richest vocabulary. The words used by the children were diverse and only some of them were repeated. This shows that 
the children have a rich vocabulary. The differences in the TTRs of the groups are not statistically significant.

Figure 4 reveals the results of retelling Tale 2. Retelling this tale, the children from Group 1 are again performing better than the children from group 2.

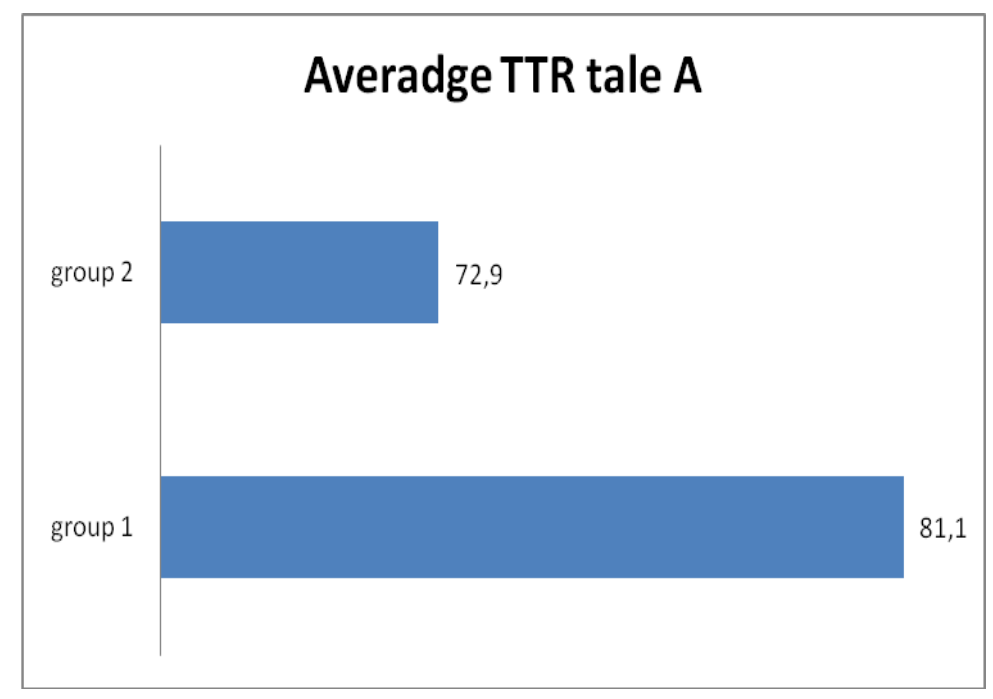

Figure 3. TTR of retelling tale A

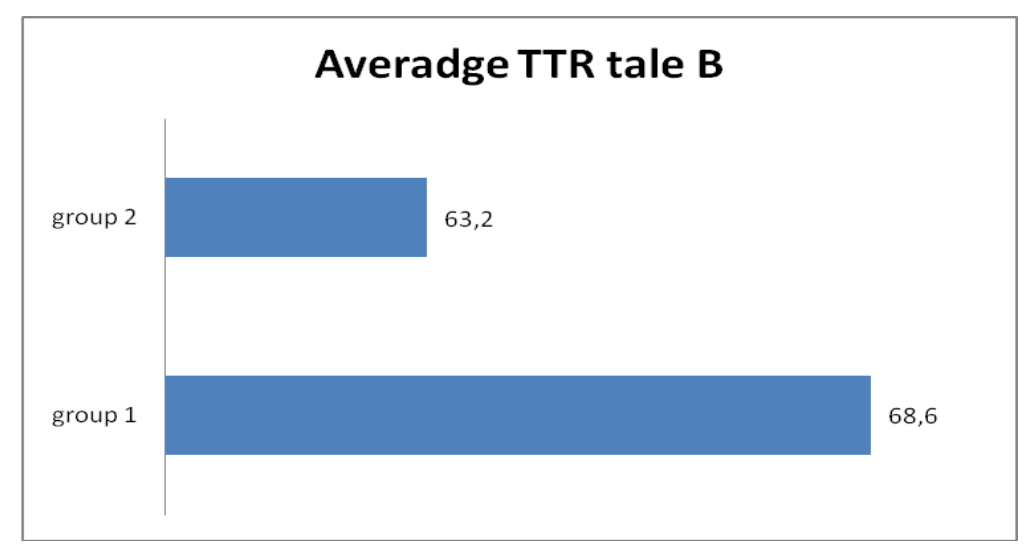

Figure 4. TTR of retelling Tale B

If we make a comparison between the separate children's TTRs, we can see that they vary from 54.8 to 85.7 in group 1 and from 58.3 to 89.4 in group 2. The results of the test with tale B are significantly lower in groups 1 and 2. Consequently, the subjects from groups 1 and 2 used less diverse words when retelling tale A. The differences between the TTR-s of the groups are not statistically significant.

The test results give us an idea about the sequence of acquisition of nouns as naming objects from the surrounding environment (nature, classroom, etc.). Abstract notions (like sun) are formed much later. The results of story retelling illustrate the mechanism of language acquisition and the level of mother tongue development. 
Children at age 6 and 7 have a rich mother tongue vocabulary acquired in the spontaneous communication with other people.

The Turkish children (group1) achieved the best results in Test 1 and Turkishspeaking Roma children (group 2) - in Test 2. The scores of group 1 and groups 2 differ by 1 point in Test 2 , i.e. they are almost equal.

The TTR of the two groups differ and the Turkish children (group 1) have higher TTR-s than the Turkish speaking Roma children (group 2). However, the differences are not statistically significant.

\subsection{Narrative competence}

The narrative competence of Turkish children living in a bilingual environment is studied by many scholars. Aarsen (1996) conducted a research on Turkish children living in the Netherlands. He evaluated the discourse skills of seven-year old children by examining text cohesion and coherence as well as anaphora. We also studied the skills of Turkish children to introduce characters in stories by two series of pictures - A story with a Horse and A story with a Cat (Kyuchukov, 2000).

Here we are going to analyze the narrative skills of the groups.

\subsection{Narrative skills}

In order to evaluate children's narrative skills, we chose three criteria for assessment of their reproduction of tales:

a) Number of sentences per a tale;

b) Number of completed episodes;

c) Number of used referents per a tale.

\section{Number of sentences in a tale}

Here we will present the numbers of the sentences per tale in figures.

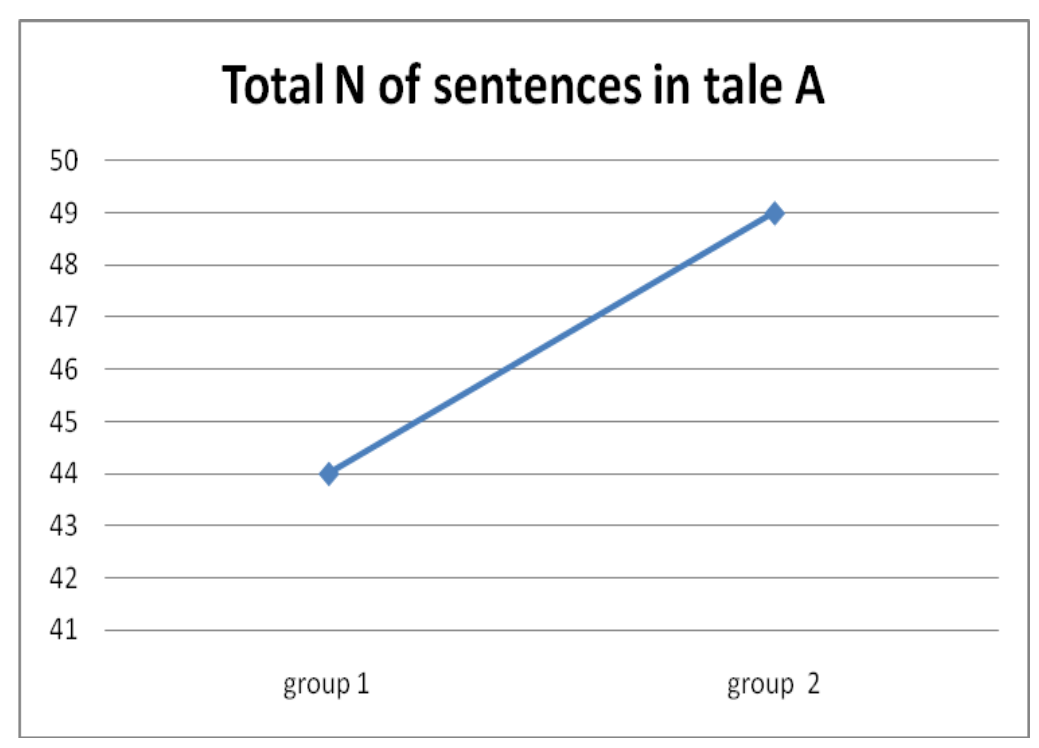

Figure 5. Total number of sentences in tale A 
Figure 5 shows that the children from group 2 have higher number of sentences per tale. However, the differences are not statistically significant. The children often narrated the story without paying attention to details thus omitting some events or just preferred to omit events. This led to a reduction of episodes. The children frequently did not complete their sentences or repeated one and the same words, which did not have any meaning or connection.

Counting the total number of sentences in tale B, we observed a significant increase as compared with tale A, which is illustrated in Figure 6.

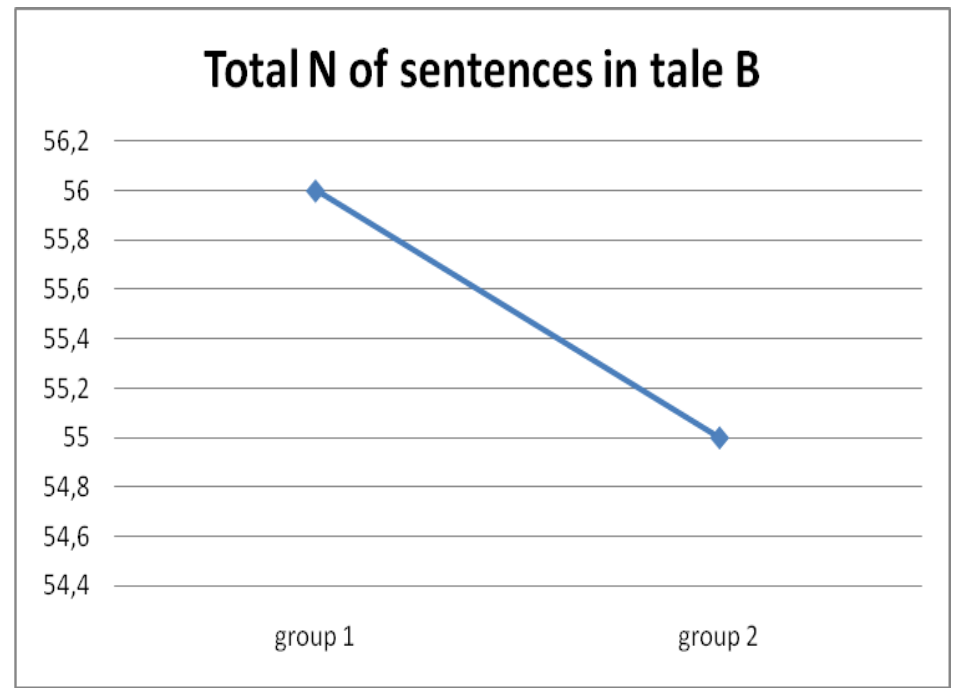

Figure 6. Total number of sentences in tale B

Although tale B was shorter than tale A, the number of sentences increased. It may be due to the two-month period between the two tests. The children have obviously improved their skills to produce texts.

If we compare the total number of sentences generated by a group, we can conclude that group 1 (Turkish children from Slaveykovo) have higher number of sentences. If we want to find out which group performed better, we must sum up the total number of generated sentences in the two tales. The result is the following:

\section{Group 1 - 105 sentences \\ Group 2 - 99 sentences}

One can see that the Turkish children form group 1 - the village of Slaveykovo have higher number of sentences in both stories than the children from group 2 - the Turkish speaking Roma children form he town of Provadiya. The reasons for the small differences could be that the children in the villages are much more use to listen and tell fairytales instead of the children from the town, where there are different possibilities for communication.

Number of completed episodes in a tale

As mentioned above, the tales were divided into completed episodes. Each episode included one situation as demonstrated by the example below: 


\section{Aç köpek}

1. Bir aç köpek bir parça kemik bulmuş. Kemiği azina almiş.

2. Şu kemiklen bir dere başindan geçmiş. Suya bakmiş.

3.Suyun içinde daha bir köpek kemiklen görmüss. Av demiş.

The Greedy Dog

Episode 1: A greedy dog found a piece of meat. It took it in its mouth.

Episode 2: It went with the meat in its mouth by the river. It looked at the water.

Episode 3: It saw another dog there. It also was carrying meat in its mouth. The dog barked.

When we compared how the children narrated different episodes of the two tales, we noticed that all groups tended to reduce and simplify the content. This signifies that they have a poor vocabulary and are not able to use figurative language in their mother tongue.

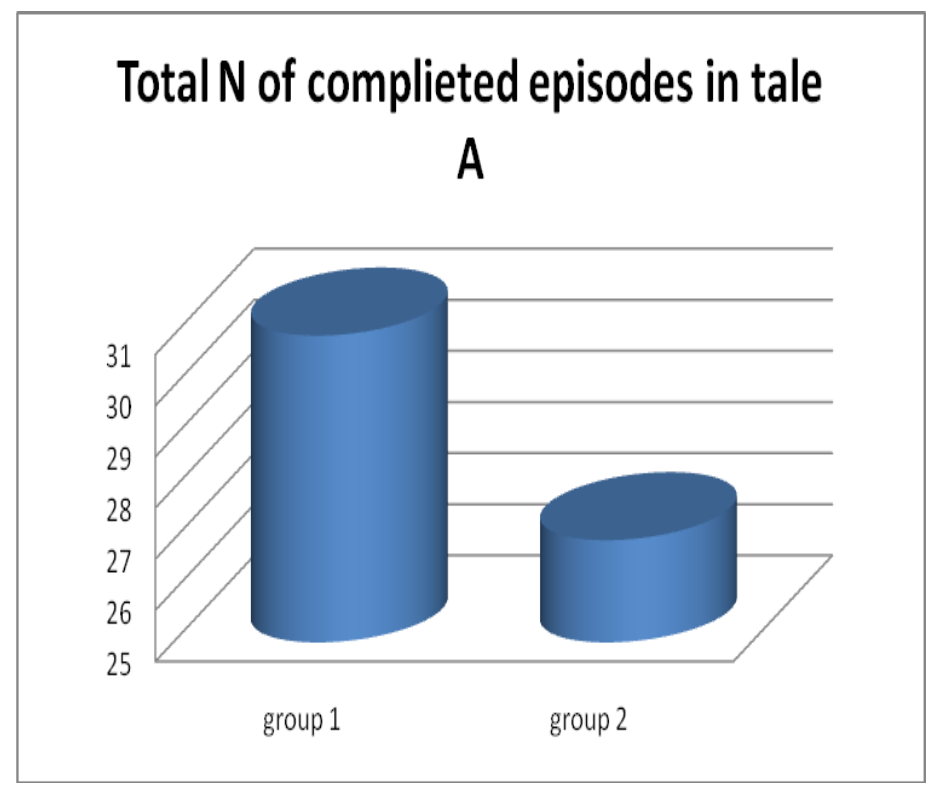

Figure 7. Total number of completed episodes in tale A

If we make a comparison between the groups, we see that the performance of group 1 is better than the performance of the children from group 2. As already mentioned, one child from group 2 refused to retell the tale, and one child reproduced just one episode. The differences between the two groups are not statistically significant. 
The results of retelling tale B are given in the next figure 8 .



Figure 8. Total number of completed episodes in tale B

The results of group 2 are higher than the results of group 1. Some children from group 1 changed the story line by introducing an episode in which the dog wanted to exchange its piece of meat with the other dog it saw in the water. This naturally affects the number of completed episodes. Therefore, the episodes in which children introduce changes to the tale are considered incomplete.

The number of episodes narrated by group 1 were reduced from 31 (tale A) to 27 (tale B) whereas the number of episodes produced by group 2 were increased from 27 to 34 . The reason is that many children having a smaller number of completed episodes in tale A, narrated more episodes in tale B, and one child who had refused to reproduce tale A, had two completed episodes of tale B.

An improvement of children's skills to retell stories without omitting episodes is observed. Therefore, their narrative skills develop at that age.

Length of thematic word chains and their referents

The thematic words in tale A selected for observation are:

$\begin{array}{ll}\text { horoz } & \text { cock } \\ \text { tilki } & \text { fox } \\ \text { köpek } & \text { dog }\end{array}$

Some children used thematic words which had not been used by the interviewer in his or her narration of the tale.

The children coined or introduced new thematic words such as:

$\begin{array}{llll}\text { balkan } & \text { instead of } & \text { orman } & \text { forest } \\ \text { kukurigu } & \text { instead of } & \text { horoz } & \text { cock }\end{array}$


Table 2

Total number of used thematic words chains and their referents in tale A

\begin{tabular}{lcc}
\hline Tale & $\begin{array}{c}\text { Group 1 } \\
\text { Slaveykovo }\end{array}$ & $\begin{array}{c}\text { Group 2 } \\
\text { Provadiya }\end{array}$ \\
\hline Tale A & 46 & 33 \\
\hline
\end{tabular}

Many children from the groups use identical thematic words and rarely substitute them, for instance, for personal pronouns. The following example illustrates how a child from group 1 narrates:

Tilki işitmiş orozum sesini. Koşuylan gelmiş orozum yanina ... The fox heard the cock's voice and ran to the cock...

or

Köpek işitmiş tilkiyi. Koşula gelmiş köpek...

The dog heard the fox. The dog came running...

Other children very skillfully and successfully use personal pronouns or the suffix for third person singular thus avoiding the repetition of one and the same words. Two children from group 1 used the Turkish personal pronoun $\boldsymbol{o}$ for third person singular and the past tense form -miş. Two children from group 2 used the Turkish personal pronoun $\boldsymbol{o}$ and a child used the Bulgarian word for fox instead the Turkish one. The average number of thematic words used in retelling tale $\mathrm{A}$ is the following:

\section{Group 1 (Turkish children) - 5.7 thematic words}

Group 2 (Turkish-speaking Romani children) - 4.1 thematic words

The Turkish children were skillful using the thematic words and the skills to work with thematic words in the group of the Turkish-speaking Roma turned out to be poorer. One possible explanation for the latter is the age of the respondents from this group - they were youngest.

The thematic words in tale B are the following:

$\begin{array}{ll}\text { köpek } & \text { dog } \\ \text { kemik } & \text { meat } \\ \text { su } & \text { water }\end{array}$

The thematic words used by the different groups are given in Table 3 . 
Table 3

Total number of used thematic word chains and their referents in tale B

\begin{tabular}{lcc}
\hline Tale & $\begin{array}{c}\text { Group 1 } \\
\text { Slaveykovo }\end{array}$ & $\begin{array}{c}\text { Group 2 } \\
\text { Provadiya }\end{array}$ \\
\hline Tale B & 59 & 74 \\
\hline
\end{tabular}

The average number of thematic words used by the groups in retelling tale B is the following:

\section{Group 1 (Turkish children) - 7.3 thematic words \\ Group 2 (Turkish-speaking Romani children) - 9.2 thematic words}

If we make a comparison between the average numbers of thematic words in tale A, we will notice an increase in the number of referents used by a group. Consequently, the children acquired skills for using thematic words during the twomonth period between the tests. The personal pronoun or the verbal suffix for third person singular is more frequently used by all groups as a strategy for avoiding repetition.

The children from group 2 have better use of thematic words, which showed an incredible improvement in tale B (with an average number of thematic words 9.2) in comparison with tale A (with an average number of thematic words 4.1). One possible explanation is that the children may had acquired skills to use referential words in an oral text during the two-month period.

We can draw a conclusion that according to our criteria, 6- and 7-year old Turkish children have narrative competence. The performance of the different groups of children was good according to the different criteria.

The evaluation of the number of sentences criterion shows that the score of the Turkish children from Slaveykovo (105 sentences) is highest. The reasons for these results may be different but, in my opinion, the basic one can be sought in the fact that children living in villages more regularly communicate with their grandparents than those living in towns and cities. It is known that grandparents are those people who narrate stories.

\section{Conclusions}

The conducted research provides interesting information about the linguistic development and socialization of Turkish speaking children at the age of 6 and 7 .

The research on children's' vocabulary show that Turkish children are better in naming objects.

We can conclude that Turkish children at the age of 6 and 7 have not mastered their mother tongue yet. This means that children should be taught in their mother tongue at kindergarten. Then developing their speech, they will be better prepared for their Bulgarian language classes when they start school. These findings and the international documents referring to mother tongue education necessitate 
amendments in the curricula of the Ministry of Education and Science, namely introducing mother tongue education in the kindergarten.

The research indicates which groups of children what gaps have in their mother tongue proficiency. Taking into consideration the Cummins' theory, according to which the bilingual children learning a second language have problems with those grammatical and linguistic categories which are not well acquired in the mother tongue of the children, we should admit that children will have problems with exactly these linguistic categories in Bulgarian. This can give teachers some ideas about what methodology to apply to the Bulgarian language teaching in order to overcome problems with these grammatical categories in the initial school grades.

This study here although limited in the number of participants, shows some important tendencies regarding the place and the role of mother tongue education for the cognitive development of bilingual children and its importance in the language interdependence theory of Cummins (1991), where the level of the mother tongue is a predictor of second language acquisition.

\section{References}

Aarssen, J. (1994) Acquisition of discourse anaphora in Turkish children's narratives. Paper presented at the VII International Conference of Turkish Linguistics, Mainz.

Akınc1, M. (2016) From Emergent bilingualism to biliteracy competences of French-Turkish bilingual children and teenagers in France. Paper presented at "The Future of Multilingualism in the German Educational System", Berlin, March 3-4.

Aksu-Koç and Slobin (1985) Acquisition of Turkish. In D. I. Slobin (Ed.), The crosslinguistic study of language acquisition: Vol. 1. The data (pp. 839-878). Hillsdale, NJ: Lawrence Erlbaum Associates

Aksu- Koç, A. (1994) Development of linguistic forms: Turkish. In: Berman, R. and Slobin, D. (eds.) Relating events in narrative. A crosslinguistic developmental study. Hillsdale, NJ: Lawrence Erlbaum Associates, Publishers.

Boeschoten, H. (1990) Acquisition of Turkish by immigrant children: a multiple case study of Turkish children in the Netherlands aged 4 to 6. Tilburg" Tilburg University Press.

Boeschoten, H. \& Verhoeven, L. (1987). "Turkish language development of Turkish children in the Netherlands. In: A. Aksu-Koç \& E. Erguvanli-Taylan (eds.), Proceedings of the Conference on Turkish Linguistics, Istanbul, 1984. Boaziçi University Press, 269-280.

Cummins, J. (1991). Interdependence of First- and Second-Language Proficiency in Bilingual Children. In E. Bialystock (Ed.), Language Processing in Bilingual Children (pp. 70-89). Cambridge: Cambridge University Press. http://dx.doi.org/10.1017/CBO9780511620652.006

Küntay, A. (1997) Extended discourse skills of Turkish preschool children across shifting contexts. Unpublished Ph. D. dissertation, Berkeley.

Kyuchukov, H. (2000) Introducing referents in Turkish children's narratives. Psychology of Language and Communication, 4(1), pp. 65-74.

Kyuchukov, H. (2007) Turkish and Roma children learning Bulgarian.

Veliko Tarnovo: Faber.

Kyuchukov, H. (2019) Za Mefkure Mollova i neyniyat prinos za izsledvane na turskite dialekti v Bulgaria. [About Mefkure Mollova and her commitment for researching the Turkish dialects in Bulgaria]. Veliko Tarnovo: Faber

Luria, A. R. and Yudevich, F. Ia. (1959) Speech and the development of mental processes in the child. London: Strapless Press 
Pfaff, C. (1993) Turkish language development in Germany. In. G. Extra and L. Verhoeven (eds) Immigrant languages in Europe. Clevedon: Multilingual Matters.

Verhallen, M. and Schoenen, R. (1993) Lexical knowledge of Monolingual and bilingual children. Applied Linguistics, 14, 344-363.

Verhoeven, L. (1993) Acquisition of narrative skills in a bilingual context. In; V. Ketteman and W. Wieden (eds) Current issues in European Second language acquisition research. Tübingen: Max Niemeyer. 